\title{
Intraspecific variation in expression of candidate genes for osmoregulation, heme biosynthesis and stress resistance suggests local adaptation in European flounder (Platichthys flesus)
}

\author{
PF Larsen ${ }^{1,2}$, EE Nielsen ${ }^{1}$, TD Williams ${ }^{3}$ and V Loeschcke ${ }^{2}$ \\ ${ }^{1}$ Department of Inland Fisheries, Danish Institute for Fisheries Research, Technical University of Denmark, Silkeborg, Denmark; \\ ${ }^{2}$ Department of Biological Sciences, University of Aarhus, Aarhus, Denmark and ${ }^{3}$ School of Biosciences, The University of Birmingham, \\ Birmingham, UK
}

\begin{abstract}
Despite the recent discovery of significant genetic structuring in a large number of marine organisms, the evolutionary significance of these often minute genetic differences are still poorly understood. To elucidate the adaptive relevance of low genetic differentiation among marine fish populations, we studied expression differences of osmoregulatory and stress genes in genetically weakly differentiated populations of the European flounder (Platichthys flesus), distributed across a natural salinity gradient. Flounders were maintained in a longterm reciprocal transplantation experiment mimicking natural salinities in the North Sea and the Baltic Sea. Applying realtime quantitative PCR and microarray analysis we studied expression of four candidate genes ( $h s p 70$, angiotensinogen, $\mathrm{Na} / \mathrm{K}$-ATPase- $\alpha$ and 5-aminolevulinic acid synthase (ALAS)) in gill, kidney and liver tissues. Genes involved in osmoregulative processes ( $\mathrm{Na} / \mathrm{K}$-ATPases- $\alpha$ and angiotensinogen) showed
\end{abstract}

highly plastic but similar expression in the two populations dependent on environmental salinity. However, we observed a unique sixfold up-regulation of $h s p 70$ in kidney tissue of flounder from the North Sea following long-term acclimation to Baltic salinities. Similarly, significant differences between North Sea and Baltic flounders in expression of ALAS in response to different salinities were found in gill and liver tissue. These findings strongly suggest that gene expression in flounders is shaped by adaptation to local environmental conditions. This identification of adaptive differences in high gene flow marine organisms adds a new dimension to our current understanding of evolutionary processes in the sea and is of paramount importance for identification, protection and sustainable management of marine biodiversity.

Heredity (2008) 101, 247-259; doi:10.1038/hdy.2008.54; published online 18 June 2008

Keywords: gene expression; quantitative PCR; local adaptation; genetic population structure; microarray

\section{Introduction}

Many species of marine fishes have large continuous distributions in the oceans and are characterized by having high dispersal abilities both as juveniles and adults. In particular the free flowing pelagic phase of eggs and larvae allows transport of these relatively passive life stages over large distances by wind and/or oceanic currents. The implication of such a high gene flow scenario caused by the specific life history characteristics of 'classical' marine fishes is that the genetic differentiation is expected to be very limited compared with most other organisms (DeWoody and Avise, 2000). Low levels of genetic structuring in marine fishes compared with freshwater and anadromous fishes has generally been confirmed by studies of genetic population structure using different types of selectively

Correspondence: Dr PF Larsen, Department of Inland Fisheries, Danish Institute for Fisheries Research, Technical University of Denmark, Vejlsøvej 39, Silkeborg, Silkeborg 8600, Denmark.

E-mail: pfl@difres.dk

Received 5 October 2007; revised 27 March 2008; accepted 26 April 2008; published online 18 June 2008 neutral genetic markers (reviewed by Ward et al., 1994; Waples, 1998). However, recent studies employing highly variable neutral genetic markers, such as microsatellites, have revealed small albeit statistically significant genetic differentiation among apparent local populations on a much smaller geographical scale than previously assumed (Knutsen et al., 2003; Nielsen et al., 2004; Jorgensen et al., 2005). These relatively weak signals of population structure have been suggested to represent semi-independent evolutionary units capable of adapting to the local environment (Conover et al., 2006).

Marine fishes inhabit a diverse array of physical and biological environments, favoring adaptive divergence among populations (Waples, 1998) and ultimately speciation (Doebeli and Dieckmann, 2003). In general high levels of neutral population differentiation for marine fishes has been shown to coincide with environmental clines (Nielsen et al., 2003; Bekkevold et al., 2005; Hemmer-Hansen et al., 2007b) providing indirect evidence of local adaptations. Recently, genetic markers associated with functional genes such as Pan I in cod (Pogson and Fevolden, 2003; Case et al., 2005) and heatshock cognate gene $(h s c 70)$ in European flounders 
(Hemmer-Hansen et al., 2007a) has demonstrated that levels of genetic differentiation associated with such genes are much higher than for neutral markers. Finally, regulatory variation in gene expression among estuarine and marine fishes has been shown to be pronounced across environmental gradients (Oleksiak et al., 2002; Picard and Schulte, 2004; Whitehead and Crawford, 2006).

Salinity is expected to be one of the most important environmental drivers for evolution in the oceans and salinity gradients have been shown to coincide with suspected adaptive population divergence in marine fishes (Nielsen et al., 2003, 2004). A very well-studied salinity gradient stretches from the high-saline North Sea into the brackish Baltic Sea (Johannesson and Andre, 2006). Along a relatively short transect $(400-500 \mathrm{~km})$ the salinity changes rapidly from marine conditions in the North Sea (33-35 p.p.t.) through the Kattegat, the Danish Belts and Øresund to brackish and almost freshwater conditions in the northeastern part of the Baltic Sea (Johannesson and Andre, 2006). Recent population genetic studies have revealed relatively high levels of genetic structuring between marine fish populations sampled in the North Sea and the Baltic Sea, respectively, with $\mathrm{F}_{\mathrm{ST}}$ values in cod (Gadus morhua), herring (Clupea harengus) and turbot (Scophthalmus maximus) ranging from 2 to 4.5\% (Nielsen et al., 2003, 2004; Bekkevold et al., 2005). Intraspecific differences in fitness-related reproductive traits were found for various populations of marine fish across the North Sea/Baltic Sea salinity gradient, for example, dab (Limanda limanda), plaice (Platichthys platessa), flounder (P. flesus) and Atlantic cod in different saline environments (Nissling and Westin, 1997; Nissling et al., 2002). Spermatozoa mobility, fertilization rates and salinity at which eggs became neutrally buoyant were measured for different local populations of marine fish maintained at different salinities (Nissling and Westin, 1997; Nissling et al., 2002), mimicking natural salinities in the Baltic Sea and in the transition area. Following transfer of individuals from marine to brackish conditions these reproductive parameters remained essentially the same and their results strongly suggested specific adaptations to local salinities for these important reproductive traits. These so-called 'local adaptations' are defined as when individuals from one population demonstrate improved fitness in their native environment compared to other populations in the same environment (Kawecki and Ebert, 2004).

Recent population genetic studies conducted on European flounder sampled across the North Sea/Baltic Sea transect have provided estimates of extremely low genetic differentiation (Larsen et al., 2007; HemmerHansen et al., 2007b). Using variation in nine microsatellite markers they found that flounders from the two areas were almost genetically identical $\left(\mathrm{F}_{\mathrm{ST}}\right.$ ranging from 0.005 to 0.006 ), thus indicating high levels of gene flow thereby reducing the likelihood of finding local adaptations within populations. However, despite the apparent lack of genetic differentiation Larsen et al. (2007) recently found strong indications of local adaptations in overall patterns of gene expression between flounder populations in the North Sea and the Baltic Sea. Assessing gene expression patterns in 3341 genes using microarray analysis they detected that 5\% (158) of genes expressed in liver tissue were significantly differently expressed in
North Sea and Baltic Sea flounders subjected to the same salinities under controlled conditions.

It is widely accepted that variation in gene expression has large functional consequences and that it is an important component for environmental adaptation among natural populations (Oleksiak et al., 2002; Babu and Aravind, 2006; Derome and Bernatchez, 2006). Little effort has, however, been diverted toward investigating how variation in gene expression could be related to osmoregulatory capacities or temperature tolerance under salinity and temperature stress in natural fish populations. However, a recent study has demonstrated an apparent strong link between expression of heatshock protein genes and fitness traits in fishes (Fangue et al., 2006). This study showed a tight coupling of thermal tolerance with expression of $h s p 70$ in gill tissue of killifish (Fundulus heteroclitus), originating from local populations inhabiting different thermal habitats (Fangue et al., 2006). Therefore, studies of the pattern and variation in 'candidate gene' expression (for example, genes involved in temperature and salinity tolerance) among natural populations shows high potential for revealing important local adaptations to different environmental conditions in fishes.

In this study we wanted to test the hypothesis of intraspecific variation in gene expression and adaptation to local marine conditions in European flounder sampled from the North Sea and the Baltic Sea. To do that we studied tissue-specific gene expression of four candidate genes for local adaptation and compare gene expression profiles from gill and kidney tissues with microarray data for expression in liver tissue. Two candidate genes for salinity adaptation, 5-aminolevulinic acid synthase $(A L A S)$ and angiotensinogen, involved in heme biosynthesis and blood pressure maintenance in fishes, respectively, were identified by Larsen et al. (2007) as the most promising candidate genes in a microarray study of gene expression variation in liver tissue. ALAS was observed to be differently expressed between flounder populations from the North Sea and the Baltic Sea, whereas angiotensinogen was identified as being highly plastic in expression dependent on salinity acclimation (Larsen et al., 2007). Moreover two previously described and highly likely candidate genes for local adaptation were included in this study, hsp70 and Na/K-ATPase- $\alpha$. Heatshock proteins, and in particular $h s p 70$, are known to be induced by multiple stressors, including osmotic stress (Sorensen et al., 2003) and $\mathrm{Na} / \mathrm{K}$-ATPases are known to be critical for maintaining ion balance and homeostasis of teleost fishes in relation to salinity acclimation (Evans et al., 2005).

We hypothesized that flounders originating from the high-saline North Sea and the brackish Baltic Sea are better adapted to their native saline environment than to nonnative conditions. Accordingly, we expected to find differences in patterns of gene expression in flounders originating from the two populations. First we measured hsp70 gene expression, which has been shown to be highly correlated with fitness in other organisms (Sorensen et al., 2003; Fangue et al., 2006). Next we measured expression of genes involved in osmoregulative processes ( $\mathrm{Na} / \mathrm{K}-\mathrm{ATP}$ ase- $\alpha$ and angiotensinogen), where we expected high plasticity under different saline conditions, potentially explaining the high euryhalinity observed for European flounder (Jensen et al., 2002). 


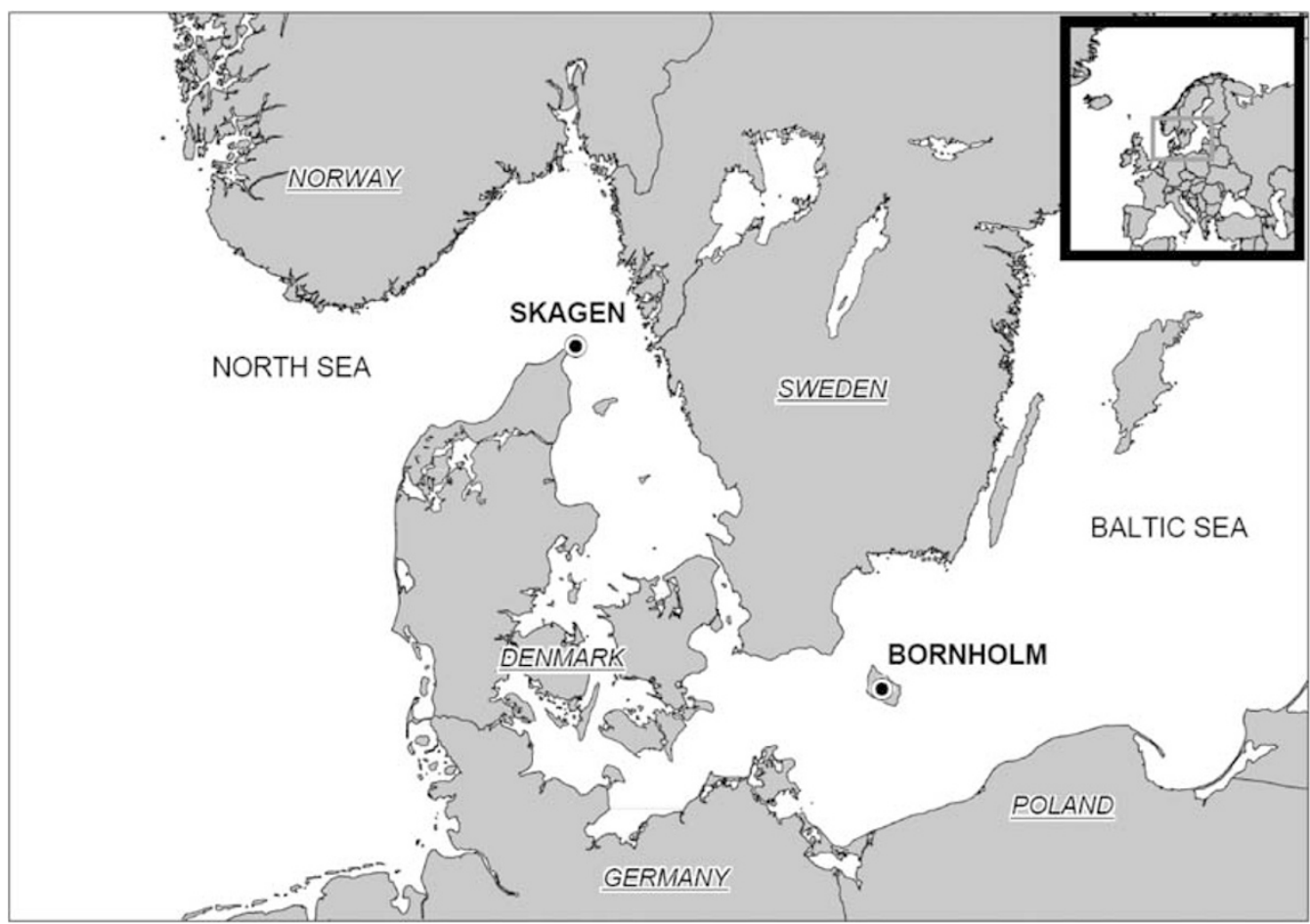

Figure 1 Map showing the flounder sampling locations Skagen and Bornholm.

Finally we quantified the expression of $A L A S$ to evaluate its expression in tissues directly involved in osmoregulation compared with the previous observations by Larsen et al. (2007) where analyses of liver tissue displayed population differences. Gene expression responses following long-term acclimation (50 days) as well as acute (1 day) were quantified to evaluate both initial and longterm regulation of stress and osmoregulative genes in different tissues. The results are discussed in relation to population structure and potential for local adaptations in a classical high gene flow marine fish species.

\section{Materials and methods}

\section{Tank experiments}

Immature European flounders were collected using dragnets from the North Sea at Skagen and in the Baltic Sea at the Island of Bornholm, Denmark (Figure 1) in August and September 2005. By the termination of the experiment sampled flounders varied in length from 10.2 to $14.5 \mathrm{~cm}$ and no significant difference in length of sampled flounders was found between locations or treatment-groups (one-way analysis of variance (ANOVA): $\left.F_{3,18}=2.142, P=0.1305\right)$. North Sea and Baltic Sea flounders were transported to the aquarium facilities at the University of Aarhus, Denmark and held at $10 \pm 0.5^{\circ} \mathrm{C}$ in 1000 -liter tanks containing recirculated water mimicking natural salinities of the North Sea (33 \pm 0.5 p.p.t.) and Baltic Sea $(9 \pm 0.5$ p.p.t.). All flounders were maintained at a $16 \mathrm{~h}$ light $/ 8 \mathrm{~h}$ dark cycle and allowed to acclimate to laboratory conditions for at least 2 months at their natural salinity prior to starting the experiments. Following acclimation, flounder from the North Sea and flounder from the Baltic Sea populations were randomly assigned to a control group and a reciprocal transplantation group with 5-6 individuals in each group (one tank for each salinity). In the transplantation experiments tank water salinity was gradually reduced from 33 to 9 p.p.t., or elevated from 9 to 33 p.p.t. to end up at reciprocal salinities, over a $2 \mathrm{~h}$ period, to minimize acute stress responses.

An experimental design of reciprocal transplantation was used to investigate differences in gene expression between the two populations of flounders sampled. Acclimation was set to 50 days to assure full acclimation (Deane and Woo, 2004). By applying the reciprocal transplantation experimental design the physical environment can be standardized and allows for studying gene expression variation depending on genetic origin associated with local adaptations (Mitchell-Olds and Schmitt, 2006). Finally, to evaluate whether flounders were in fact stressed in response to salinity changes following reciprocal transfer, we conducted a short-term experiment, where flounders were sampled following 1 day at nonnatural reciprocal salinities to study whether flounders were in fact physiologically stressed following transplantation.

Flounders were initially fed with rainbow trout (Oncorhynchus myskiss) and mussels (Mytilus edulis) cut into pieces, but later food was supplemented with commercial trout pellets (BioMar, Denmark), up to 5 days before they were killed. No acute stress effects, such as behavioral changes or death, were evident within the experimental period. All experiments were carried out according to Danish legislation concerning the use of experimental animals.

\section{Tissue collection and RNA extraction}

Following termination of the tank experiment approximately $150 \mathrm{mg}$ of gill, kidney and liver tissue was 

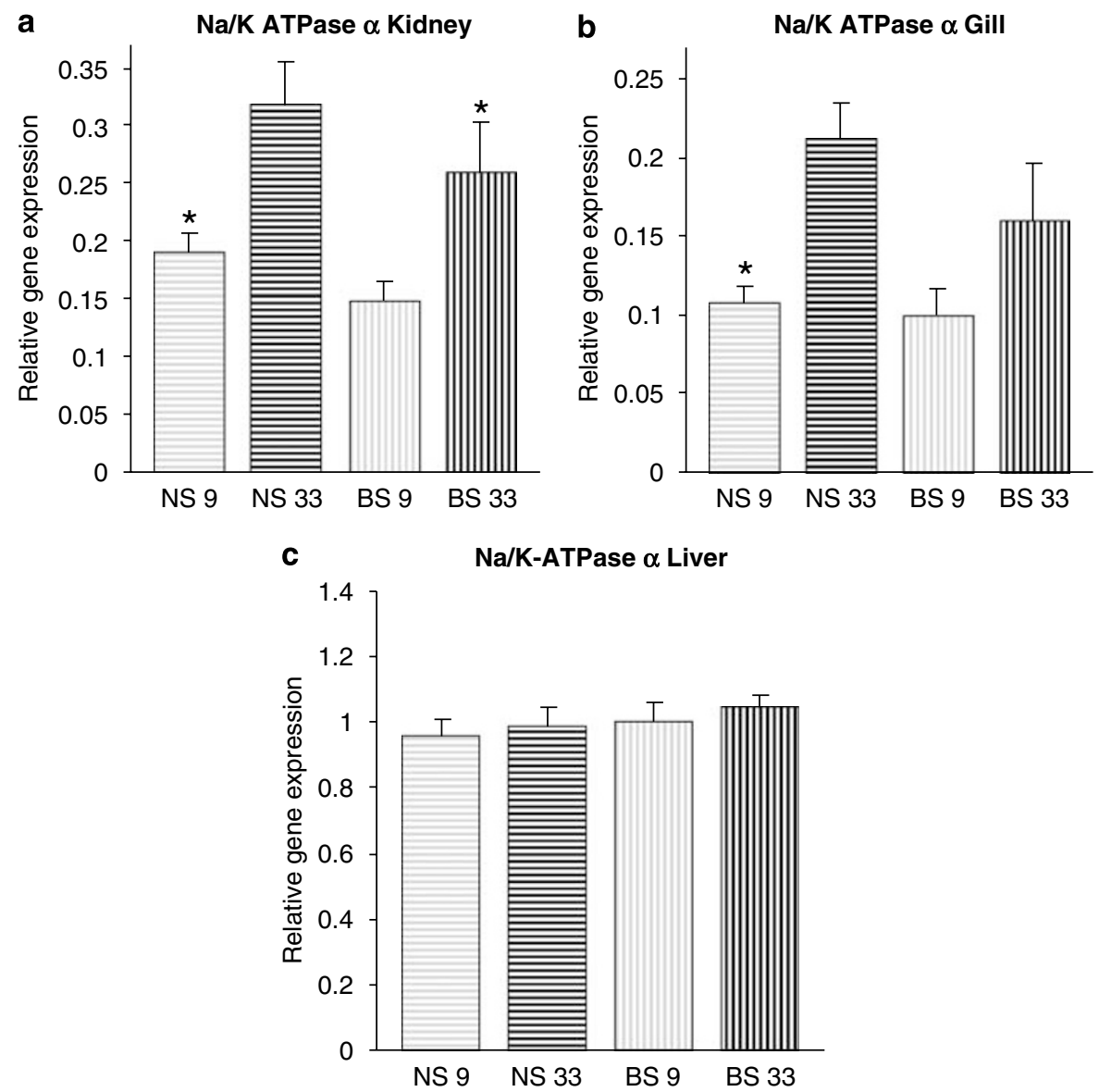

Figure 2 Expression of $\mathrm{Na} / \mathrm{K}-\mathrm{ATPase}-\alpha$ subunit in kidney (a), gill (b) and liver (c) tissue from North Sea (NS) and Baltic Sea (BS) flounders following long-term acclimation to brackish (9 p.p.t.) and seawater salinities (33 p.p.t.). Amount of mRNA in control and reciprocal transplanted samples are normalized to the corresponding elongation factor $1 \alpha(E F 1 \alpha)$ abundance from the same sample, and mean (number of fish in each group $=5$ to 6$)$ values are expressed in arbitrary units \pm s.e. ( ${ }^{*}$ significantly different between salinity treatments $(P<0.05)$ ).

dissected and immediately placed in RNase-free Eppendorf tubes containing excess RNAlater following the manufacturer's instructions (Qiagen, Hilden, Germany). RNAlater-preserved samples were stored at $-20{ }^{\circ} \mathrm{C}$ until being processed for RNA extraction.

Total RNA was extracted using the RNeasy minikit (Qiagen). Tissue $(20 \mathrm{mg}$ ) was removed from the RNAlater preservation solution and immediately immersed in $600 \mu \mathrm{l}$ of RLT buffer containing $\beta$-mercapthoethanol. The tissue was then homogenized using a Tissue-Tearor rotor homogenizer (BioSpec Products, Bartlesville, OK, USA). Extractions were performed as recommended by the manufacturer except for an additional DNAse treatment step for $15 \mathrm{~min}$ at $25^{\circ} \mathrm{C}$ to remove any remaining genomic DNA. Finally, total RNA was eluted from the Qiagen spin columns using two times $30 \mu \mathrm{l}$ of RNAse-free water and stored at $-20^{\circ} \mathrm{C}$. Concentration of extracted RNA was determined at $260 \mathrm{~nm}$ in a standard Hellma cuvette (path length $10 \mathrm{~mm}$ ) using the GeneQuant II (RNA/DNA Calculator; Pharmacia Biotech, Uppsala, Sweden). Total RNA quality was routinely analyzed using $2 \%$ agarose gel electrophoresis and applying capillary electrophoresis with the Agilent 2100 bioanalyzer (Agilent Technologies, Palo Alto, CA, USA).

\section{Reverse transcription of RNA and real-time quantitative PCR}

Reverse transcription of total RNA into cDNA was performed using the SuperScriptII RNase H-Reverse Transcriptase kit (Invitrogen, Carlsbad, CA, USA) in a reaction volume of $20 \mu \mathrm{l}$ containing $1 \times$ reaction buffer, $5 \mathrm{mM} \mathrm{MgCl}_{2}, 1 \mathrm{mM}$ deoxyribonucleotide triphosphate mixture, $0.3 \mu \mathrm{l}$ of anchored oligo- $(\mathrm{dT})_{20}$ primer $\left(2.5 \mu \mathrm{g} \mu \mathrm{l}^{-1}\right), 1 \mu \mathrm{l}$ of SuperScriptII reverse transcriptase and $3 \mu \mathrm{g}$ of total RNA. Following reverse transcription, samples were diluted by 10 -fold and stored at $-20^{\circ} \mathrm{C}$ until analysis.

For the real-time quantitative PCR (qRT-PCR) analysis gene-specific primer pairs were designed using the Primer-3 software (Rozen and Skaletsky, 2000) based on sequences available in GenBank. Primer sets were developed for the following $P$. flesus genes: 5-aminolevulinic acid synthase (ALAS) (GenBank accession no. AJ302076); ALAS-F 5'-aggaacagcggtgctaagaa-3', ALAS-R, $5^{\prime}$-tctcaaaggccacgatcttc- $3^{\prime}$ product size $109 \mathrm{bp}$; angiotensinogen precursor (GenBank accession no. DV567747); angio-F 5'-ccaggaggacaagctactg-3', angio-R 5'-gctgctg gagttcagctctt- $3^{\prime}$ product size $89 \mathrm{bp}$, hsp70 (GenBank accession no. AF187726); hsp70-F 5'-acaagagagctgtccgt cgt-3', hsp70-R 5'-ctccctcatacagggagtcg- $3^{\prime}$ product size 

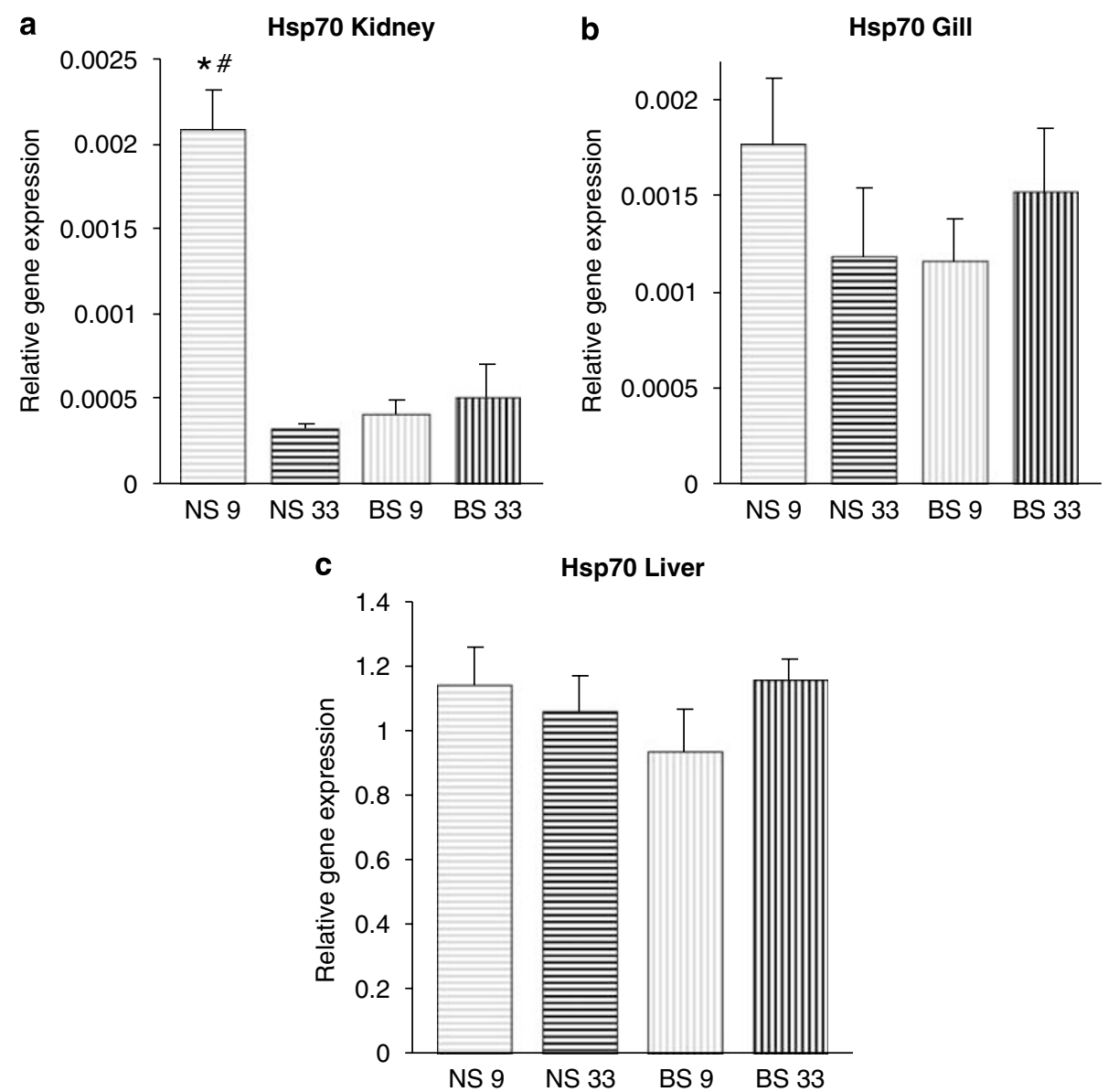

Figure 3 Expression of $h s p 70$ in kidney (a), gill (b) and liver (c) tissue from North Sea (NS) and Baltic Sea (BS) flounder following long-term acclimation to brackish (9 p.p.t.) and seawater salinities (33 p.p.t.). Amount of mRNA in control and reciprocal transplanted samples are normalized to the corresponding elongation factor $1 \alpha(\mathrm{EF} 1 \alpha)$ abundance from the same sample, and mean (number of fish in each group $=$ $5-6)$ values are expressed in arbitrary units \pm s.e. (*significantly different between salinity treatments $(P<0.05)$, "\#significantly different between populations at the same salinity $(P<0.05))$.

$103 \mathrm{bp}, \quad N a / K-A T P a s e-\alpha$ subunit (GenBank accession no. DV566003); NaATP $\alpha-\mathrm{F} \quad 5^{\prime}$-aatcgcatcctcatcttgg-3', $\mathrm{NaATP} \alpha-\mathrm{R} \quad 5^{\prime}$-tggcttgaggggatacattc- $3^{\prime}$ product size $105 \mathrm{bp}$ and the housekeeping gene elongation factor $1 \alpha$ $(E F 1 \alpha)$ (GenBank accession no. EC378684); EF1 $\alpha-F$ $5^{\prime}$-ccaggaggacaagctactg- $3^{\prime}$, EF1 $\alpha-\mathrm{R} 5^{\prime}$-gctgctggagttcagctc tt- $3^{\prime}$ product size $89 \mathrm{bp}$.

PCR products from all primer pairs were checked on a $2 \%$ agarose gel to verify primer specificity and PCR product length and to ensure that they only produced a single amplicon when flounder cDNA served as template. Furthermore, dilution series were performed to verify amplification efficiency of primer pairs (Stahlberg et al., 2004).

qRT-PCR was performed on the Ligthcycler 1.2 (Roche Diagnostics, Mannheim, Germany) using SYBR Green chemistry (LigthCycler FastStart DNA Master SYBR Green I kit; Roche) and the Lightcycler relative quantification software 3.5 (Roche Diagnostics). Using this software we employed the fully automated method for $C_{\mathrm{T}}$ determination called the '2nd Derivative Maximum' calculation. The $C_{T}$ value is the cycle where the second derivative is at its maximum and ideally this should always be in the heart of the log-linear portion of the reaction. Moreover this method is more objective and reproducible than human-mediated crossing point settings (Lightcycler relative quantification software manual). All qRT-PCR reactions were performed as follows: $10 \mathrm{~min}$ at $95^{\circ} \mathrm{C}$, followed by 40 cycles of $95^{\circ} \mathrm{C}$ for $15 \mathrm{~s}, 60^{\circ} \mathrm{C}$ for $10 \mathrm{~s}$ and $72{ }^{\circ} \mathrm{C}$ for $10 \mathrm{~s}$. Melting curve analysis was performed following each reaction to confirm the presence of only a single product in the reaction. Negative control reactions were performed for all samples using RNA that had not been reverse transcribed to control for the possible presence of genomic DNA contamination. Genomic DNA contamination was present in most samples, but never constituted more than 1:3000 of starting cDNA copy numbers (data not shown). Therefore genomic DNA contamination reflects only a minor fraction of the final PCR product and only a minimum source of error for the data analysis. In the present paper gene expression results for kidney and gill tissues are produced from qRT-PCR analysis, whereas gene expression results for liver tissue are based on normalized microarray data from the same fishes (microarray raw data are available from ArrayExpress, accession no. E-MAXD-22). Information on normalization and analysis of microarray results are available in Larsen et al. (2007). 

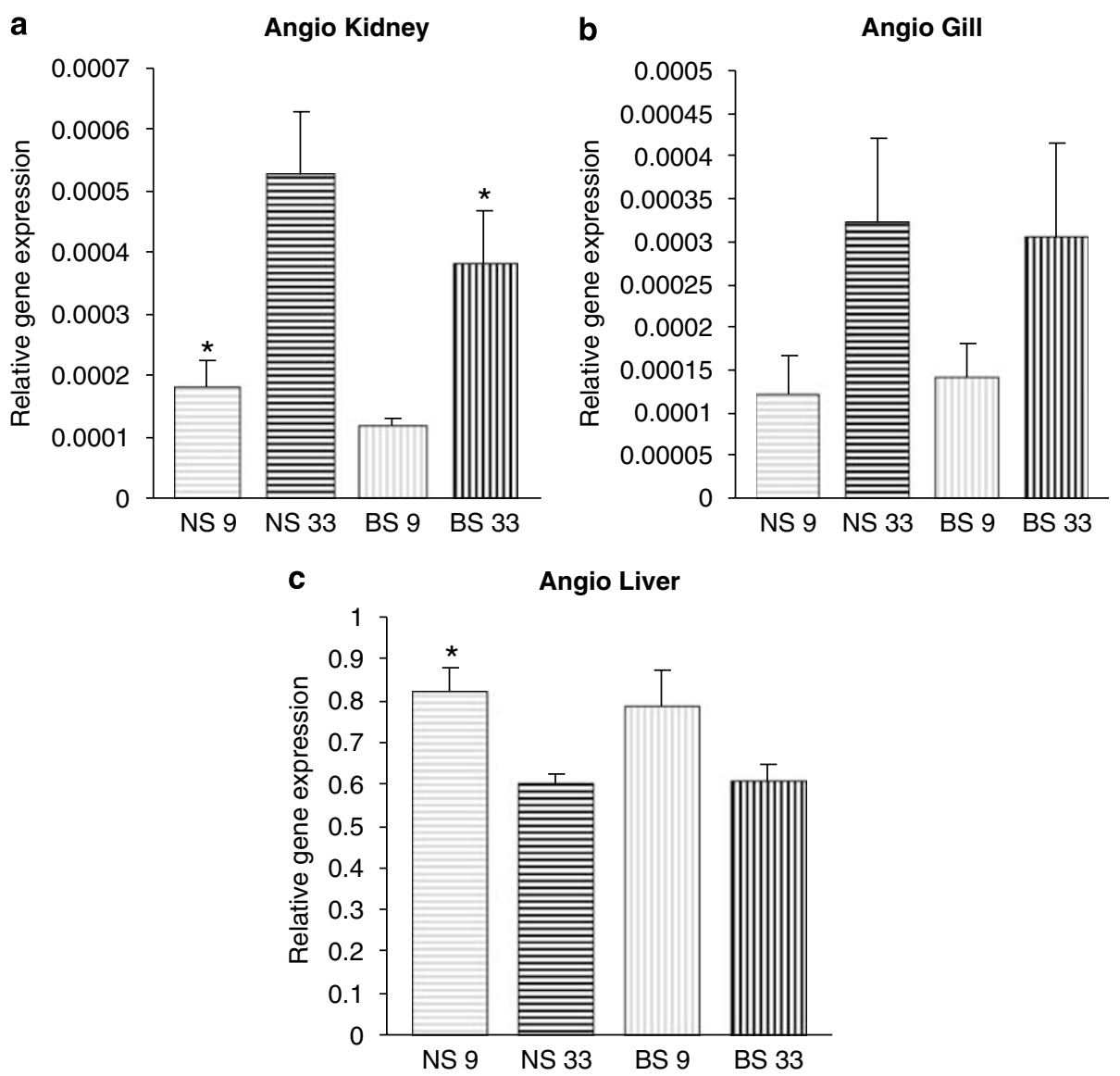

Figure 4 Expression of angiotensinogen in kidney (a), gill (b) and liver (c) tissue from North Sea (NS) and Baltic Sea (BS) flounder following long-term acclimation to brackish (9 p.p.t.) and seawater salinities (33 p.p.t.). Amount of mRNA in control and reciprocal transplanted samples are normalized to the corresponding elongation factor $1 \alpha(E F 1 \alpha)$ abundance from the same sample, and mean (number of fish in each group $=5$ to 6$)$ values are expressed in arbitrary units \pm s.e. ( ${ }^{*}$ significantly different between salinity treatments $(P<0.05)$ ).

\section{Statistical analysis}

Relative gene expression values were calculated using the 'Comparative method' according to Livak and Schmittgen, (2001). Data are presented as mean expression levels \pm s.e. Gene expression levels were compared using one-way ANOVA (fixed effects model), and multiple pairwise comparisons were conducted using Tukeys test between salinities (within populations) or between populations (maintained at the same salinity). Finally, two-way ANOVA was conducted to test for an interaction effect of salinity treatment and population origin. Significance level was set at $\alpha=0.05$ in all analyses and analyses were conducted using the PAST statistics software (Hammer et al., 2001).

\section{Results}

\section{Long-term experiment}

No mortality was observed throughout the period of the experiment. In the long-term experiment the $\mathrm{Na} / \mathrm{K}$ ATPase- $\alpha$ subunit gene was observed to be expressed 1.5- to 2-fold higher at high salinities than at low salinities in kidney and gill tissues from both populations (Figures 2a and b). For North Sea flounder this variation was significant both in kidney $(P=0.012)$ and gill tissues $(P=0.0014)$, whereas for Baltic Sea flounder this variation was only significant in kidney $(P=0.033)$ but close to significant in gill tissue $(P=0.069)$. Furthermore, no significant differences were observed in expression of the $\mathrm{Na} / \mathrm{K}$-ATPase- $\alpha$ gene in liver tissue in any population (Figure 2c). Hsp70 was found to be sixfold upregulated in kidney of transplanted North Sea flounder $(P=0.0002)$, whereas no differences were observed in Baltic Sea flounder in kidney tissue, or in gill and liver tissues for any treatment (Figure 3). Similar to the $\mathrm{Na} / \mathrm{K}$-ATPase- $\alpha$ subunit we observed that expression of the angiotensinogen gene was positively correlated with salinity in both kidney and gill tissue (Figures 4a and $b$ ), although expression differences were only significant in kidney tissue in both populations (North Sea, $P=0.006$; Baltic Sea, $P=0.045)$. In liver tissue, expression of angiotensinogen was reversed compared to kidney and gill tissue, with a negative correlation between expression and salinity. The difference was significant between treatments for North Sea flounders $(P=0.021)$ (Figure $4 \mathrm{c})$ and close to significant between treatments for Baltic Sea flounders $(P=0.082)$. Finally, for the ALAS gene we observed a significant difference in expression for North Sea flounder in kidney tissue $(P=0.003)$ acclimated to high and low salinities 
a

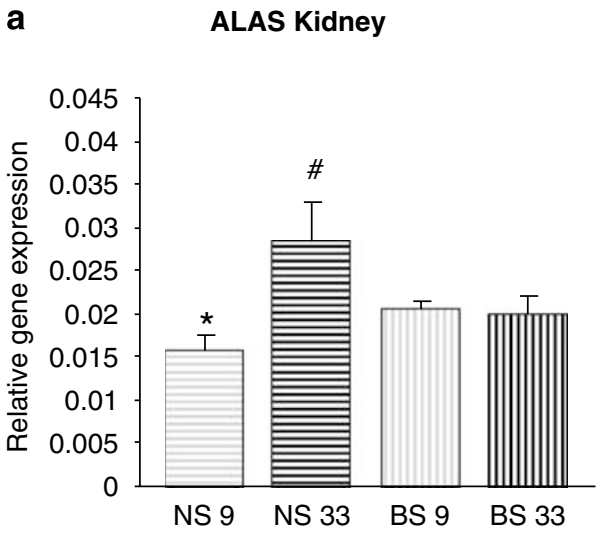

b
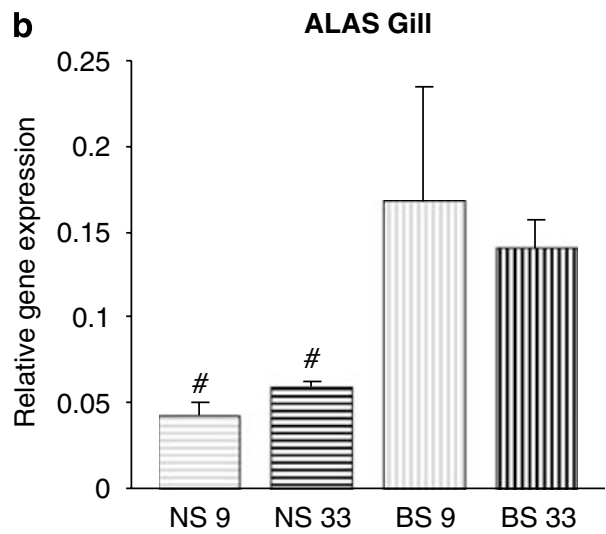

C ALAS Liver

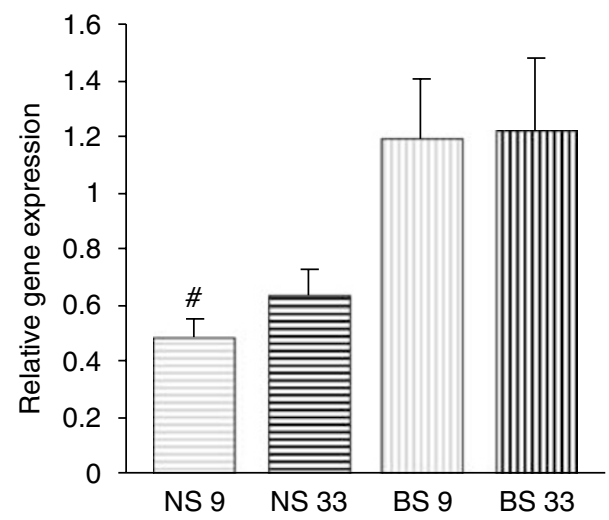

Figure 5 Expression of 5-aminolevulinic acid synthase (ALAS) in kidney (a), gill (b) and liver (c) tissue from North Sea (NS) and Baltic Sea (BS) flounder following long-term acclimation to brackish (9p.p.t.) and seawater salinities (33 p.p.t.). Amount of mRNA in control and reciprocal transplanted samples are normalized to the corresponding elongation factor $1 \alpha(\mathrm{EF} 1 \alpha)$ abundance from the same sample, and mean (number of fish in each group $=5$ to 6 ) values are expressed in arbitrary units \pm s.e. (*significantly different between salinity treatments $(P<0.05)$, " significantly different between populations at the same salinity $(P<0.05))$.

(Figure 5a). In gill and liver tissues we detected significant differences in gene expression of $A L A S$ between populations, which apparently were independent of salinity acclimation with the highest expression of ALAS in Baltic Sea flounder in both gill and liver tissues (Figures $5 b$ and $c$ ).

Conducting two-way ANOVA on gene expression data from the long-term experiment we identified significant effects of salinity treatment for $\mathrm{Na} / \mathrm{K}-\mathrm{ATPase}-\alpha$ gene expression in both kidney $(P=0.0005)$ and gill tissue $(P=0.002)$, whereas expression of angiotensinogen was only significantly affected by salinity in kidney tissue $(P=0.003 ; \quad$ gill tissue marginally nonsignificant $P=0.061)$. In gill and liver tissues a significant effect of population origin was identified in the expression of $A L A S$, independently of salinity acclimation (gill, $P=0.023$; liver, $P=0.0013$ ). In North Sea flounder a significant interaction effect of salinity $(P=0.000447)$ and origin ( $P=0.001214)$ was observed in expression of $h s p 70$ in kidney tissue $(P=0.000685)$.

\section{Short-term experiment}

In the short-term experiment we observed significant induction of $h s p 70$ in kidney, gill and liver tissue in flounder from both populations acclimated to reciprocal salinities (Figure 6). The expression level of the $\mathrm{Na} / \mathrm{K}$ -
ATPase- $\alpha$ gene were significantly upregulated in kidney tissue of transplanted North Sea flounder following short-term acclimation, whereas in gill tissue the $\mathrm{Na} / \mathrm{K}$ ATPase- $\alpha$ subunit was significantly downregulated in transplanted North Sea flounder (Figures 7a and b). No significant differences were observed in expression of $\mathrm{Na} / \mathrm{K}$-ATPase in kidney or gill in Baltic Sea flounder but an indication of upregulation at high salinities was observed in gill tissue (Figure $7 \mathrm{~b}$ ). No variation in expression of $\mathrm{Na} / \mathrm{K}$-ATPase- $\alpha$ was observed in liver tissues for any population (Figure 7c). The angiotensinogen gene was more highly expressed at high salinities compared to low salinities in kidney tissue although this difference was only significant for North Sea flounder (Figure 8a). In gill tissue the expression of angiotensinogen was 2.5-fold upregulated in transplanted North Sea flounder and in liver tissue fourfold upregulated in transplanted Baltic Sea flounder (Figures $8 \mathrm{~b}$ and c). Finally the ALAS gene was found to be significantly downregulated in the kidney of transplanted North Sea flounder, whereas no differences were observed for Baltic Sea flounder (Figure 9a). In both liver and gill tissue (Figures $9 \mathrm{~b}$ and c) strong indications for populationspecific gene expression profiles was observed, and in liver tissue $A L A S$ gene expression was found to be only marginally nonsignificant (9 p.p.t., $P=0.053 ; 33$ p.p.t., $P=0.069$ ). 

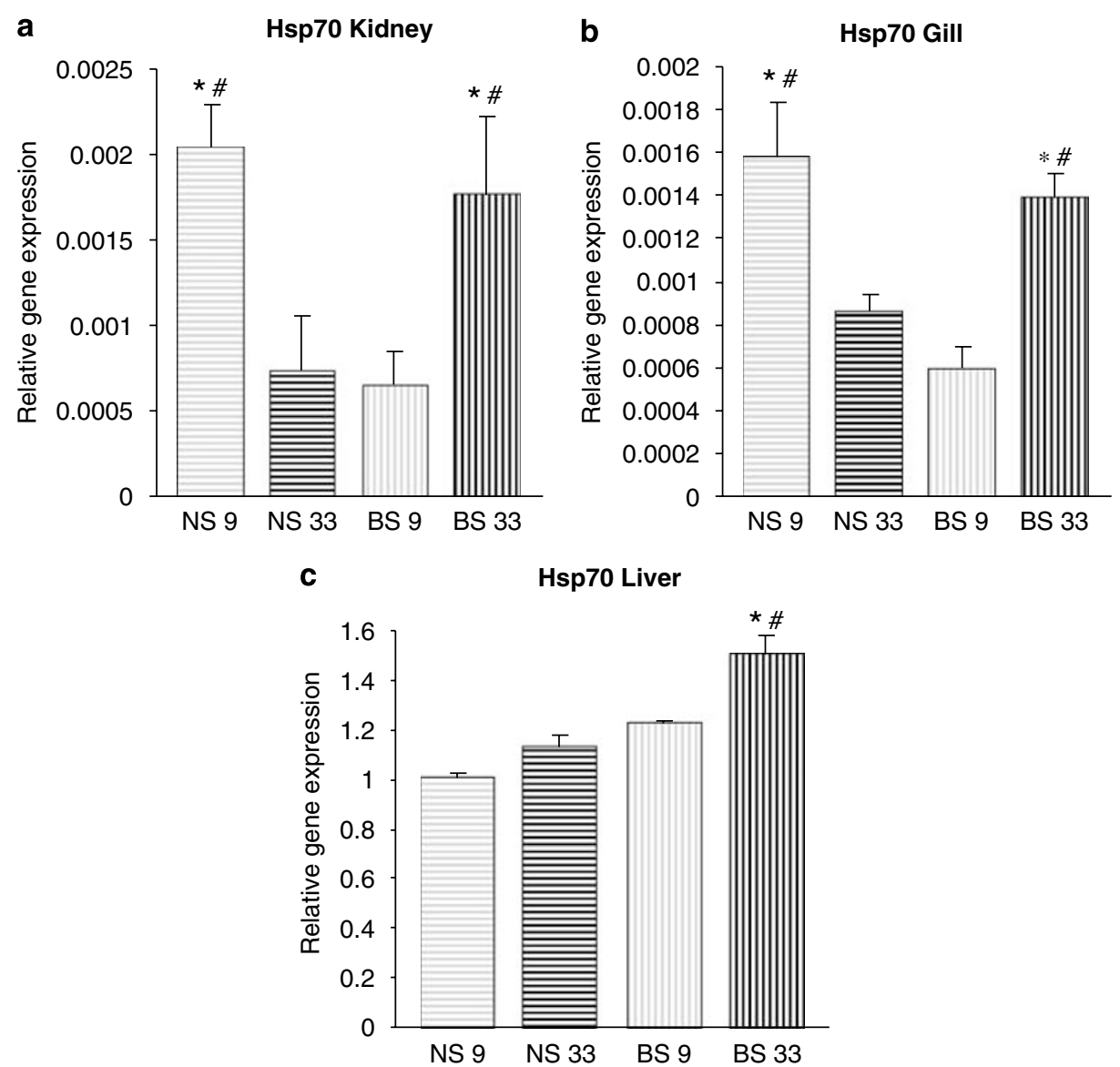

Figure 6 Expression of $h s p 70$ in kidney (a), gill (b) and liver (c) tissue from North Sea (NS) and Baltic Sea (BS) flounder following short-term acclimation to brackish (9 p.p.t.) and seawater salinities (33 p.p.t.). Amount of mRNA in control and reciprocal transplanted samples are normalized to the corresponding elongation factor $1 \alpha(\mathrm{EF} 1 \alpha)$ abundance from the same sample, and mean (number of fish in each group $=5$ ) values are expressed in arbitrary units \pm s.e. (*significantly different between salinity treatments $(P<0.05)$, " significantly different between populations at the same salinity $(P<0.05))$.

\section{Discussion}

Our main objective in this study was to test the hypothesis that variation in gene expression could explain adaptation to different saline conditions in European flounder distributed across the salinity gradient from the high-saline North Sea into the brackish Baltic Sea. Quantifying gene expression of four candidate genes in three different tissues we show (1) intraspecific differences in expression profiles of the ALAS gene in gill and liver tissue resulting from genetic origin of flounders, (2) high plasticity in gene expression dependent on salinity acclimation for both $\mathrm{Na} / \mathrm{K}-\mathrm{ATPase}-\alpha$ and angiotensinogen in kidney and gill tissues and finally (3) an interaction effect between salinity treatment and genetic origin in expression of $h s p 70$ in kidney tissue of North Sea flounder resulting from a dramatic increase in expression of $h s p 70$ in transplanted North Sea flounder.

The ALAS gene was differently expressed between flounder populations in both gill and liver tissues and $A L A S$ has previously been shown to be highly important for the iron/heme biosynthesis (Astner et al., 2005) primarily catalyzing the first step of heme biosynthesis (Schranzhofer et al., 2006). The observation of constitutive intraspecific variation in expression of $A L A S$ across several tissues underlines the functional importance of the observed variation. Furthermore, such intraspecific variation in expression of genes involved in heme biosynthesis could potentially reflect adaptation to different environmental conditions (Larsen et al., 2007). Furthermore, hemoglobin from teleost fishes shows the most extensive variation in oxygen affinities among vertebrates, reflecting the very diverse habitats inhabited by fishes (Weber and Fago, 2004). Therefore our results strongly suggest that variation in expression of the $A L A S$ gene and other genes involved in hemoglobin synthesis could help explain adaptation among marine fish populations inhabiting different saline environments. However, the direct adaptive significance of the observed variation in regulation of the ALAS gene in different tissues is unknown. Therefore, future work should focus on identifying functional links among gene expression, environmental salinity, evolution and the effects on individual phenotype and fitness of flounder from different populations in different saline environments.

High plasticity in gene expression in kidney and gill tissues, positively correlated with environmental salinity, has previously been described for $N a / K-A T P a s e-\alpha$ in several fishes, for example, Atlantic salmon (Salmo salar), rainbow trout (O. mykiss), Arctic char (Salvelinus alpinus), sea bream (Sparus sarba) and killifish (F. heteroclitus) (Deane and Woo, 2004; Scott and Schulte, 2005; 

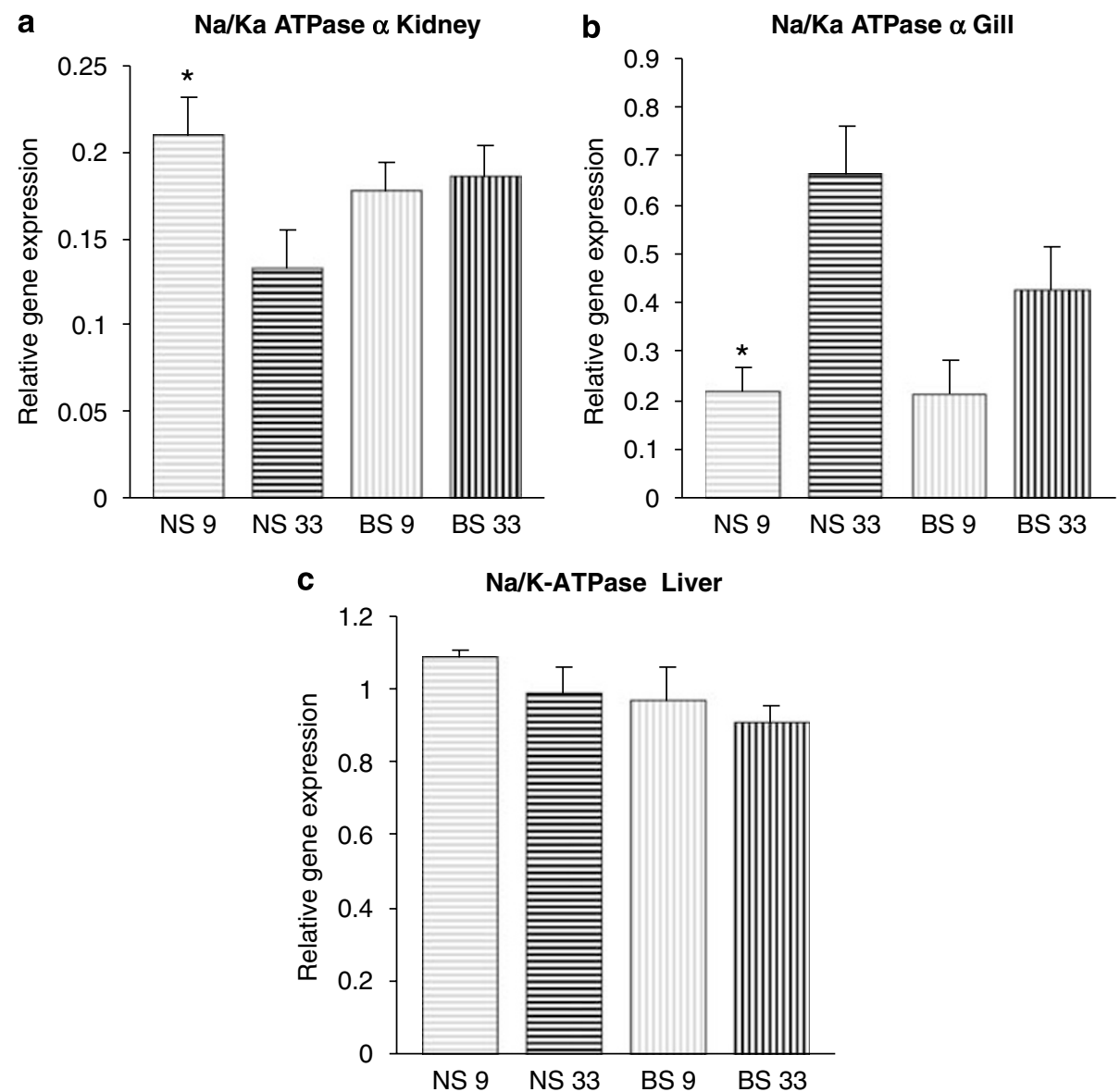

Figure 7 Expression of $\mathrm{Na} / \mathrm{K}$-ATPase- $\alpha$ in kidney (a), gill (b) and liver (c) tissue from North Sea (NS) and Baltic Sea (BS) flounder following short-term acclimation to brackish (9 p.p.t.) and seawater salinities (33 p.p.t.). Amount of mRNA in control and reciprocal transplanted samples are normalized to the corresponding elongation factor $1 \alpha(\mathrm{EF} 1 \alpha)$ abundance from the same sample, and mean (number of fish in each group $=5)$ values are expressed in arbitrary units \pm s.e. ( ${ }^{*}$ significantly different between salinity treatments $(P<0.05)$ ).

Bystriansky et al., 2006). However, salinity-regulated angiotensinogen gene expression has previously only been described in the euryhaline elasmobranch (Carcharhinus leucas) (Anderson et al., 2006) and in sea bream (S. sarba) (Wong et al., 2006). Thus, both of these osmoregulative genes are known to be important in the maintenance of fluid homeostasis in vertebrates and previous studies have suggested a potential regulatory role of angiotensinogen on Na/K-ATPase expression (Wong et al., 2006). $\mathrm{Na} / \mathrm{K}-\mathrm{ATP}$ ase is primarily involved in ion regulation, whereas angiotensinogen is involved in maintenance of blood pressure in different saline environments (Wong et al., 2006). Wong et al. (2006) recently observed that abrupt transfer of silver sea bream to hypoosmotic conditions rapidly changed plasma and branchial angiotensinogen and $\mathrm{Na} / \mathrm{K}$-ATPase levels. In this study we observed very similar responses for North Sea flounder transplanted into a hypoosmotic environment. However, our results also showed that Baltic Sea flounders, following abrupt transfer into hypersaline conditions, drastically increased angiotensinogen expression in liver tissue. As the liver has been described as the primary organ for production of circulating angiotensinogen (Wong et al., 2007), this signals an immediate initiation of osmoregulative processes following transplantation into a hyperosmotic environment.
Hsp70 was identified as a candidate gene for detecting physiological stressful conditions in flounder in both the short- and long-term experiment. Population-specific differences in induction of heat-shock proteins (particularly $h s p 70$ ), a gene known to be involved in homeostasis maintenance (as a molecular chaperone) under stressful conditions, strongly signals adaptive differences between populations (Sorensen et al., 2003). We showed that North Sea flounders following long-term acclimation to low Baltic Sea salinities had a sixfold upregulation of $h s p 70$ in kidney tissue indicating high physiological stress and reduced fitness (Sorensen et al., 2003). The observation of induction of heat-shock protein genes in transplanted North Sea flounder corresponds with previous results from a microarray experiment of gene expression in European flounder by Larsen et al. (2007). They showed that North Sea flounder transplanted into Baltic Sea conditions had a significant upregulation of another chaperone (hsp90) in liver tissue following long-term acclimation to reciprocal salinities (Larsen et al., 2007).

The observation of marked differences in gene expression between flounder populations strongly indicating reduced fitness in transplanted individuals is somewhat surprising in the light of almost complete lack of neutral genetic divergence detected by Larsen et al. (2007) and 

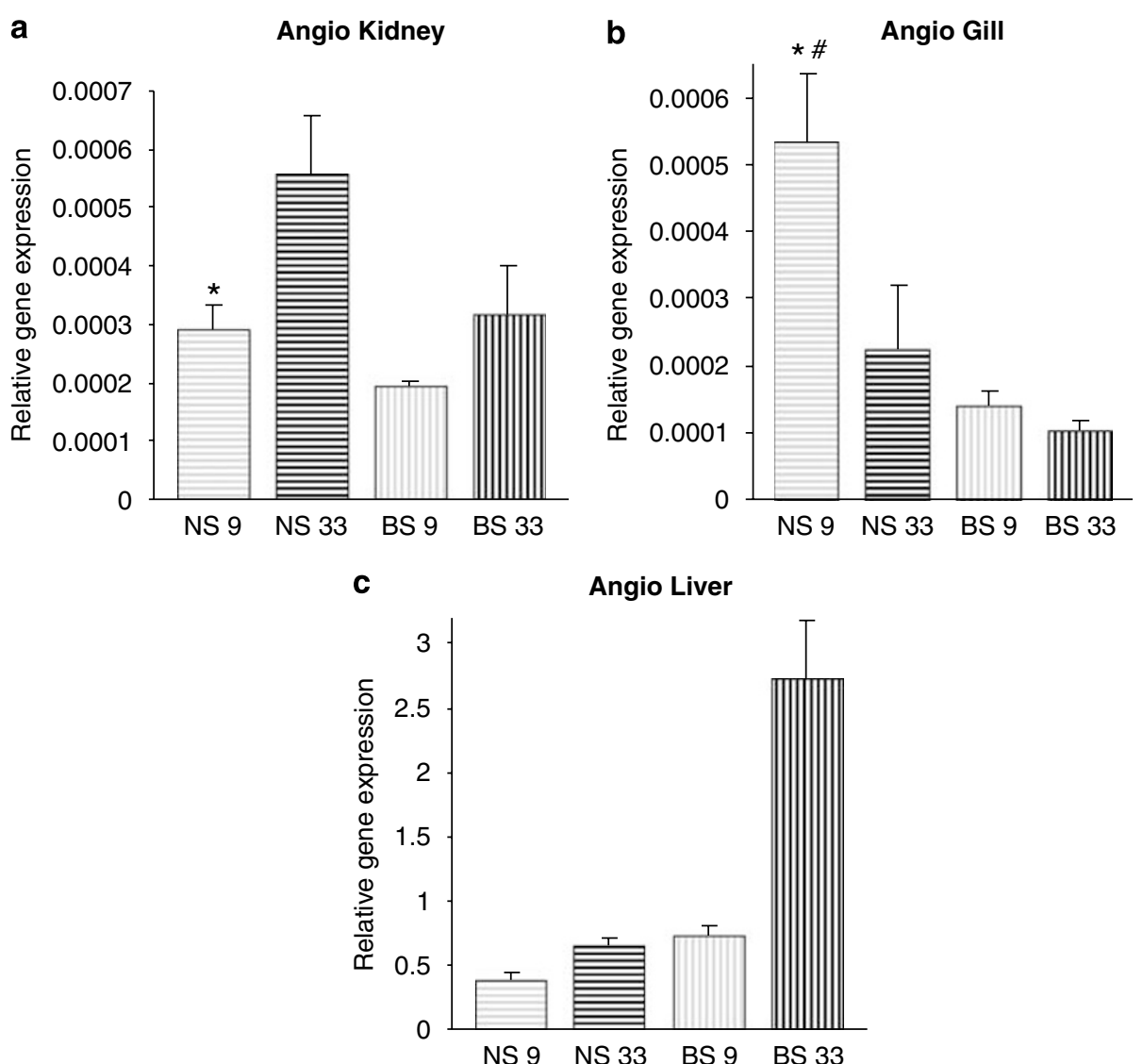

Figure 8 Expression of angiotensinogen in kidney (a), gill (b) and liver (c) tissue from North Sea (NS) and Baltic Sea (BS) flounder following short-term acclimation to brackish (9 p.p.t.) and seawater salinities (33 p.p.t.). Amount of mRNA in control and reciprocal transplanted samples are normalized to the corresponding elongation factor $1 \alpha(E F 1 \alpha)$ abundance from the same sample, and mean (number of fish in each group $=5)$ values are expressed in arbitrary units \pm s.e. ( ${ }^{*}$ significantly different between salinity treatments $(P<0.05)$, \#significantly different between populations at the same salinity $(P<0.05))$.

Hemmer-Hansen et al. (2007a). However, based on the results presented here, combined with previous studies on genetic structure in flounder (Hemmer-Hansen et al., 2007a), we propose that flounder populations are differently adapted to their native saline environments. This 'environmental adaptation' is most obvious for North Sea flounder, for example, as reflected by $h s p 70$ induction in kidney tissue, whereas it is less clear for Baltic Sea flounder. In this study we showed that Baltic Sea flounder appears to be much better to acclimate to changing salinities, that is, high-saline North Sea conditions, which correspond with previous observations by Larsen et al. (2007). They found 73 genes, or $2.3 \%$ of the 3144 genes analyzed, to be significantly differently expressed between North Sea flounders kept at native and reciprocal salinities, whereas for Baltic Sea flounder they only identified 16 genes $(0.5 \%)$ differently expressed between salinity treatments (Larsen et al., 2007). The apparent higher flexibility of Baltic Sea flounders could reflect differences in the physical stability of the native environments inhabited by the two flounder populations. Baltic Sea flounders, sampled at the Island of Bornholm, experience larger interannual changes in their saline environment, with occasional inflow of high-saline water from the North Sea and a steady outflow of lowsaline brackish water from the inner part of the Baltic Sea (Jakobsen, 1995; Rodhe and Winsor, 2002). On the contrary, the salinity in the North Sea is much more stable on an annual basis with only minor fluctuations in salinity. These differences in environmental salinity could have resulted in the evolution of increased osmoregulatory capacity in Baltic Sea flounders to cope with large salinity fluctuations in the western part of the Baltic Sea, whereas North Sea flounder show signs of reduced osmoregulatory capacity most likely because they have adapted to almost constant seawater salinities in the North Sea and therefore do not possess the same tolerance for large fluctuations in salinity.

\section{Evolutionary realistic scenario?}

The likelihood that suggested environmental adaptation in flounder populations represents true genetically based selective responses to the local environments relies critically on whether the local adaptations in Baltic Sea flounders can be explained in a realistic evolutionary scenario. First of all, we need to know whether sufficient time/generations have past since the formation of the Baltic Sea to allow for adaptive differences to arise. This in turn depends on the strength of selection for salinity tolerance that is unknown but expected to be high. However, indirect evidence from the so-called 'bankflounders' that have adopted a benthic spawning strategy in response to extreme low-saline conditions in 

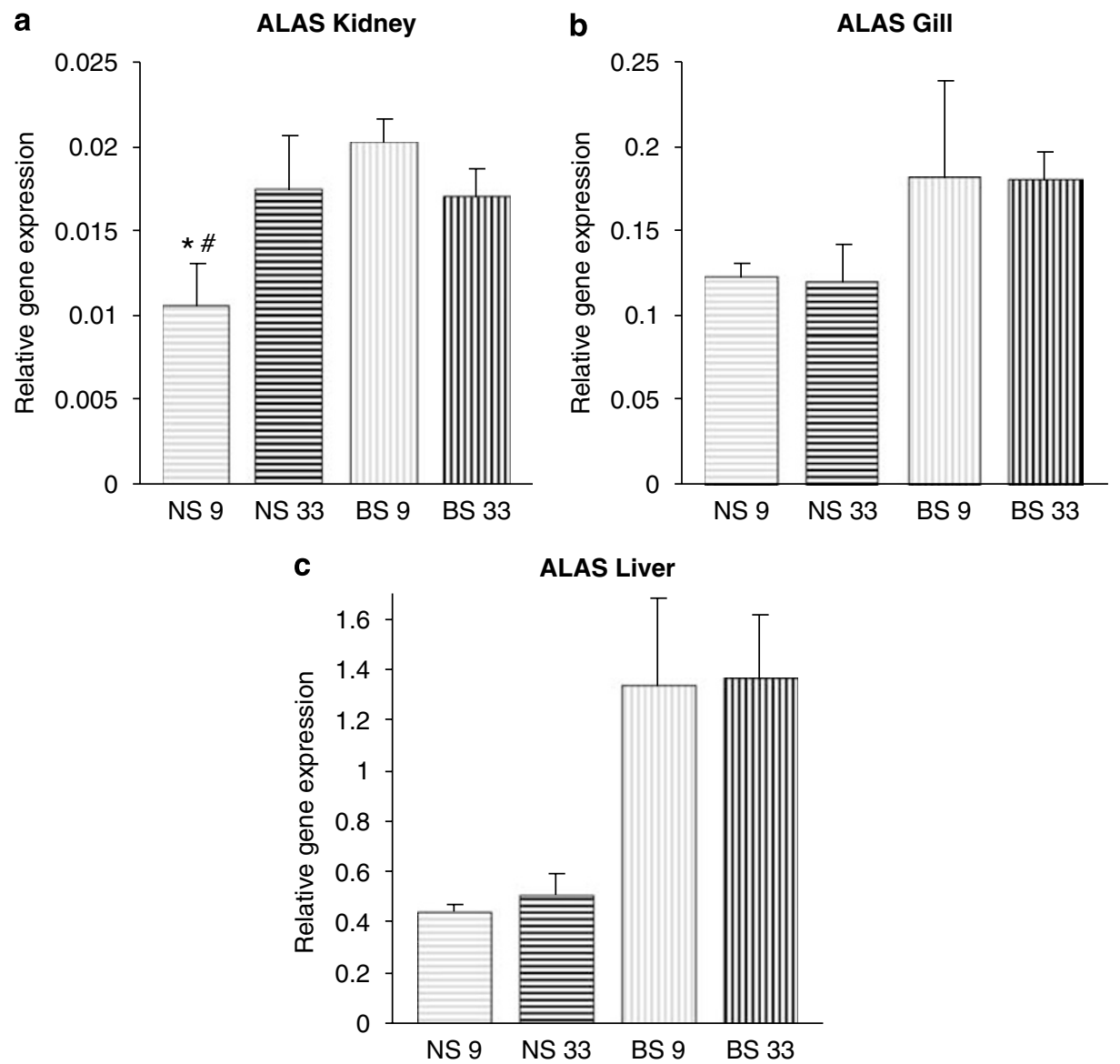

Figure 9 Expression of 5-aminolevulinic acid synthase (ALAS) in kidney (a), gill (b) and liver (c) tissue from North Sea (NS) and Baltic Sea (BS) flounder following short-term acclimation to brackish (9 p.p.t.) and seawater salinities (33 p.p.t.). Amount of mRNA in control and reciprocal transplanted samples are normalized to the corresponding elongation factor $1 \alpha(\mathrm{EF} 1 \alpha)$ abundance from the same sample, and mean (number of fish in each group $=5$ ) values are expressed in arbitrary units \pm s.e. (*significantly different between salinity treatments $(P<0.05)$, "significantly different between populations at the same salinity $(P<0.05))$.

the inner part of the Baltic Sea (Nissling et al., 2002) indicates that salinity adaptations within the last 8000 years (since the formation of the present form of the Baltic Sea (Bjorck, 1995)) are indeed possible. Accordingly, we believe that the above-suggested evolutionary scenario for differential gene expression in North Sea and Baltic Sea flounders is not unlikely. As indicated by our results flounders have adapted to high and stable salinities in the North Sea. We also find it likely that other flounder populations in the transition zone between the North Sea and the inner Baltic Sea may have evolved alternative strategies to survive and reproduce in a broader salinity window, for example, around the island of Bornholm. Thus, we cannot exclude that flounder populations have not reached drift/ migration equilibrium offering an alternative explanation than high gene flow for the low levels of genetic differentiation observed between flounder populations in the North Sea and the Baltic Sea. Still, other marine fish species that also colonized the Baltic Sea after the last ice age, for example, Atlantic cod and turbot clearly show high levels of genetic divergence among populations, $\mathrm{F}_{\mathrm{ST}}=0.045$ and 0.032 between populations from North Sea and Baltic Sea (Nielsen et al., 2003, 2004). This strongly suggests that sufficient time is likely to have passed for populations to display marked genetic differentiation (Hemmer-Hansen et al., 2007b). Generally several parameters have been described as important for promoting genetic differentiation in marine organisms, including hydrologic, topographic, physical and life history parameters. Hydrologic parameters, including oceanographic circulation currents, have been identified as important for shaping population structure in European flounders (Hemmer-Hansen et al., 2007b). In addition, also physical parameters, such as temperature, salinity, oxygen concentration, ocean depth and pollution gradients have been described to be important for creating population structure in marine fishes. Wellknown examples include both latitudinal differences in temperature on the east coast of North America and salinity differences in the transition zone from the highsaline North Sea into the brackish Baltic Sea, where several studies have demonstrated high levels of genetic differentiation, isolation by distance and local adaptation among populations (Nielsen et al., 2003, 2004; Scott and Schulte, 2005; Adams et al., 2006; Fangue et al., 2006; Larsen et al., 2007; Hemmer-Hansen et al., 2007a). Alternatively, environmental variation can also result in changes in important life history parameters that potentially can result in subdivision in marine fishes. A good example is found for European flounder in the Baltic Sea where flounders have adapted to nearly 
freshwater condition in the most northern part of the Baltic Sea. In this area flounders have been reported to have changed the spawning strategy from pelagic to benthic (Nissling et al., 2002). Under marine conditions flounders are known to spawn pelagic eggs, thus, the so-called 'bank' flounders tend to spawn benthic eggs on shallow water most likely due to low salinity resulting in the eggs sinking to unfavorable oxygen conditions on the ocean bottom (Nissling et al., 2002). Accordingly, a major genetic barrier has recently been demonstrated between the two life history forms in the Baltic Sea (HemmerHansen et al., 2007a).

For this study flounders were caught as juveniles, with no differences in size, and they were treated identically in the laboratory. Furthermore, high heritability (Schadt et al., 2003; Brem and Kruglyak, 2005) and adaptive divergence (Whitehead and Crawford, 2006; Larsen et al., 2007) is generally observed for gene expression profiles. Therefore, we find it unlikely that nongenetic factors, such as maternal, early developmental or epigenetic effects arising from interplay between genetic and environmental components should affect gene regulation when individuals are maintained in a long-term reciprocal transplantation setup.

The observation of stress responses in flounder transplanted to nonnative saline habitats in this study and previously described by Larsen et al. (2007) has important bearings in relation to a future scenario of global change. Increased rainfall is expected to lower the salinity in the Baltic Sea in the future imposing even further salinity stress on the Baltic population. Therefore, this study underlines the importance of understanding population structure in the sea, not only focusing on neutral markers presenting information about drift and migration, but also focusing on genes and expression of genes involved in local adaptation and stress responses. Further knowledge on the presence of local adaptation among marine fish populations will increase our possibility to properly manage marine fishes, and improve our ability to predict the distribution and abundance of marine species in the light of the changing evolutionary forces imposed by global change.

\section{Acknowledgements}

We thank Palle Holm Hansen for help with fish maintenance, Karen-Lise Dons Mensberg and Dorte Meldrup for assistance in the laboratory and Henrik Baktoft for graphical assistance. This project was supported by grants to Peter Foged Larsen from the SLIP research school under the Danish Network for Fisheries and Aquaculture Research financed by the Danish Ministry for Food, Agriculture and Fisheries and the Danish Agricultural and Veterinary Research Council, the Danish Institute for Fisheries Research and the Elisabeth and Knud Petersens Foundation.

\section{References}

Adams SM, Lindmeier JB, Duvernell DD (2006). Microsatellite analysis of the phylogeography, Pleistocene history and secondary contact hypotheses for the killifish, Fundulus heteroclitus. Mol Ecol 15: 1109-1123.

Anderson WG, Pillans RD, Hyodo S, Tsukada T, Good JP, Takei $Y$ et al. (2006). The effects of freshwater to seawater transfer on circulating levels of angiotensin II, C-type natriuretic peptide and arginine vasotocin in the euryhaline elasmobranch, Carcharhinus leucas. Gen Comp Endocrinol 147: 39-46.

Astner I, Schulze JO, van den Heuvel J, Jahn D, Schubert WD, Heinz DW (2005). Crystal structure of 5-aminolevulinate synthase, the first enzyme of heme biosynthesis, and its link to XLSA in humans. EMBO J 24: 3166-3177.

Babu MM, Aravind L (2006). Adaptive evolution by optimizing expression levels in different environments. Trends Microbiol 14: 11-14.

Bekkevold D, Andre C, Dahlgren TG, Clausen LA, Torstensen $\mathrm{E}$, Mosegaard $\mathrm{H}$ et al. (2005). Environmental correlates of population differentiation in Atlantic herring. Evolution 59: 2656-2668

Bjorck S (1995). A review of the history of the Baltic Sea, 13.0-8.0 Ka Bp. Quat Int 27: 19-40.

Brem RB, Kruglyak L (2005). The landscape of genetic complexity across 5,700 gene expression traits in yeast. Proc Natl Acad Sci USA 102: 1572-1577.

Bystriansky JS, Richards JG, Schulte PM, Ballantyne JS (2006). Reciprocal expression of gill $\mathrm{Na}+/ \mathrm{K}+-$ ATPase alpha-subunit isoforms alpha $1 \mathrm{a}$ and alpha $1 \mathrm{~b}$ during seawater acclimation of three salmonid fishes that vary in their salinity tolerance. J Exp Biol 209: 1848-1858.

Case RAJ, Hutchinson WF, Hauser L, Van Oosterhout C, Carvalho GR (2005). Macro- and micro-geographic variation in pantophysin (PanI) allele frequencies in NE Atlantic cod Gadus morhua. Mar Ecol Prog Ser 301: 267-278.

Conover DO, Clarke LM, Munch SB, Wagner GN (2006). Spatial and temporal scales of adaptive divergence in marine fishes and the implications for conservation. J Fish Biol 69: 21-47.

Deane EE, Woo NYS (2004). Differential gene expression associated with euryhalinity in sea bream (Sparus sarba). Am J Physiol Regul Integr Comp Physiol 287: R1054-R1063.

Derome N, Bernatchez L (2006). The transcriptomics of ecological convergence between 2 limnetic coregonine fishes (Salmonidae). Mol Biol Evol 23: 2370-2378.

DeWoody JA, Avise JC (2000). Microsatellite variation in marine, freshwater and anadromous fishes compared with other animals. J Fish Biol 56: 461-473.

Doebeli M, Dieckmann U (2003). Speciation along environmental gradients. Nature 421: 259-264.

Evans DH, Piermarini PM, Choe KP (2005). The multifunctional fish gill: dominant site of gas exchange, osmoregulation, acid-base regulation, and excretion of nitrogenous waste. Physiol Rev 85: 97-177.

Fangue NA, Hofmeister M, Schulte PM (2006). Intraspecific variation in thermal tolerance and heat shock protein gene expression in common killifish, Fundulus heteroclitus. J Exp Biol 209: 2859-2872.

Hammer $\varnothing$, Harper DAT, Ryan PD (2001). PAST: paleontological statistics software package for education and data analysis. Palaeontologia Electronica 4: 9.

Hemmer-Hansen J, Nielsen EE, Frydenberg J, Loeschcke V (2007a). Adaptive divergence in a high gene flow environment: $\mathrm{Hsc70}$ variation in the European flounder (Platicthys flesus L.). Heredity 99: 592-600.

Hemmer-Hansen J, Nielsen EE, Grønkjær P, Loeschcke V (2007b). Evolutionary factors shaping the genetic population structure of marine fishes; lessons from the European flounder (Platichthys flesus L.). Mol Ecol 16: 3104-3118.

Jakobsen F (1995). The major inflow to the Baltic Sea during January 1993. J Mar Syst 6: 227-240.

Jensen FB, Lecklin T, Busk M, Bury NR, Wilson RW, Wood CM et al. (2002). Physiological impact of salinity increase at organism and red blood cell levels in the European flounder (Platichthys flesus). J Exp Mar Biol Ecol 274: 159-174.

Johannesson K, Andre C (2006). Life on the margin: genetic isolation and diversity loss in a peripheral marine ecosystem, the Baltic Sea. Mol Ecol 15: 2013-2029. 
Jorgensen $\mathrm{HBH}$, Hansen MM, Bekkevold D, Ruzzante DE, Loeschcke V (2005). Marine landscapes and population genetic structure of herring (Clupea harengus L.) in the Baltic Sea. Mol Ecol 14: 3219-3234.

Kawecki TJ, Ebert D (2004). Conceptual issues in local adaptation. Ecol Lett 7: 1225-1241.

Knutsen H, Jorde PE, Andre C, Stenseth NC (2003). Fine-scaled geographical population structuring in a highly mobile marine species: the Atlantic cod. Mol Ecol 12: 385-394.

Larsen PF, Nielsen EE, Williams TD, Hemmer-Hansen J, Chipman JK, Kruhøffer M et al. (2007). Adaptive differences in gene expression in European flounder (Platichthys flesus). Mol Ecol 16: 4674-4683.

Livak KJ, Schmittgen TD (2001). Analysis of relative gene expression data using real-time quantitative PCR and the 2-[Delta][Delta] $C_{\mathrm{T}}$ method. Methods 25: 402-408.

Mitchell-Olds T, Schmitt J (2006). Genetic mechanisms and evolutionary significance of natural variation in Arabidopsis. Nature 441: 947-952.

Nielsen EE, Hansen MM, Ruzzante DE, Meldrup D, Gronkjaer P (2003). Evidence of a hybrid-zone in Atlantic cod (Gadus morhua) in the Baltic and the Danish Belt Sea revealed by individual admixture analysis. Mol Ecol 12: 1497-1508.

Nielsen EE, Nielsen PH, Meldrup D, Hansen MM (2004). Genetic population structure of turbot (Scophthalmus maximus L.) supports the presence of multiple hybrid zones for marine fishes in the transition zone between the Baltic Sea and the North Sea. Mol Ecol 13: 585-595.

Nissling A, Westin L (1997). Salinity requirements for successful spawning of Baltic and Belt Sea cod and the potential for cod stock interactions in the Baltic Sea. Mar Ecol Prog Ser 152: 261-271.

Nissling A, Westin L, Hjerne O (2002). Reproductive success in relation to salinity for three flatfish species, dab (Limanda limanda), plaice (Pleuronectes platessa), and flounder (Pleuronectes flesus), in the brackish water Baltic Sea. ICES J Mar Sci 59: 93-108.

Oleksiak MF, Churchill GA, Crawford DL (2002). Variation in gene expression within and among natural populations. Nat Genet 32: 261-266.

Picard DJ, Schulte PM (2004). Variation in gene expression in response to stress in two populations of Fundulus heteroclitus. Comp Biochem Physiol A Mol Integr Physiol 137: 205-216.

Pogson GH, Fevolden SE (2003). Natural selection and the genetic differentiation of coastal and Arctic populations of the Atlantic cod in northern Norway: a test involving nucleotide sequence variation at the pantophysin (PanI) locus. Mol Ecol 12: 63-74.

Rodhe J, Winsor P (2002). On the influence of the freshwater supply on the Baltic Sea mean salinity. Tellus Ser A Dyn Meteorol Oceanogr 54: 175-186.

Rozen S, Skaletsky HJ (2000). Primer3 on the WWW for general users and for biologist programmers. In: Krawetz $S$, Misener S (eds). Bioinformatics Methods and Protocols: Methods in Biology. Humana Press, Totowa, NJ, pp 365-386.

Schadt EE, Monks SA, Drake TA, Lusis AJ, Che N, Colinayo V et al. (2003). Genetics of gene expression surveyed in maize, mouse and man. Nature 422: 297-302.

Schranzhofer M, Schifrer M, Cabrera JA, Kopp S, Chiba P, Beug $\mathrm{H}$ et al. (2006). Remodeling the regulation of iron metabolism during erythroid differentiation to ensure efficient heme biosynthesis. Blood 107: 4159-4167.

Scott GR, Schulte PM (2005). Intraspecific variation in gene expression after seawater transfer in gills of the euryhaline killifish Fundulus heteroclitus. Comp Biochem Physiol A Mol Integr Physiol 141: 176-182.

Sorensen JG, Kristensen TN, Loeschcke V (2003). The evolutionary and ecological role of heat shock proteins. Ecol Lett 6: 1025-1037.

Stahlberg A, Hakansson J, Xian XJ, Semb H, Kubista M (2004). Properties of the reverse transcription reaction in mRNA quantification. Clin Chem 50: 509-515.

Waples RS (1998). Separating the wheat from the chaff: patterns of genetic differentiation in high gene flow species. J Heredity 89: 438-450.

Ward RD, Woodwark M, Skibinski DOF (1994). A comparison of genetic diversity levels in marine, fresh-water, and anadromous fishes. J Fish Biol 44: 213-232.

Weber RE, Fago A (2004). Functional adaptation and its molecular basis in vertebrate hemoglobins, neuroglobins and cytoglobins. Respir Physiol Neurobiol 144: 141-159.

Whitehead A, Crawford DL (2006). Neutral and adaptive variation in gene expression. Proc Natl Acad Sci USA 103 $5425-5430$.

Wong MKS, Ge W, Woo NYS (2007). Positive feedback of hepatic angiotensinogen expression in silver sea bream (Sparus sarba). Mol Cell Endocrinol 263: 103-111.

Wong MKS, Takei Y, Woo NYS (2006). Differential status of the renin-angiotensin system of silver sea bream (Sparus sarba) in different salinities. Gen Comp Endocrinol 149: 81-89. 